\title{
Economic Evaluation Model of Seaports' Performance Outlining Competitive Advantages and Disadvantages
}

\author{
${ }^{1}$ Nicolaus Copernicus University \\ Gagarina 13a , 87-100 Torun, Poland \\ E-mail.aranka@umk.pl \\ ${ }^{2,3}$ Klaipeda University \\ Minijos st. 153, 93185 Klaipeda, Lithuania \\ E-mail.ek.smf@ku.lt,j.bogatova@gmail.com \\ cross $^{\text {ref }}$ http://dx.doi.org/10.5755/j01.ee.29.5.21363
}

Aranka Ignasiak-Szulc ${ }^{1}$, Vytautas Juscius², Bogatova Jelena ${ }^{3}$

\begin{abstract}
Ports are a significant part of the global and regional cargo supply chain and transport network. Since the performance of ports has a significant impact on the economic growth of their countries, it is necessary to constantly analyse and plan port performance, to anticipate market trends and to improve the ability of a port to withstand the increasing overall competitive pressure. In port performance, not only physical ability to handle the flow of cargo, but also the potential competition for cargo is important. The methods presented in the scientific literature provide with an opportunity to evaluate only the technical efficiency of ports, completely excluding the aspect of financial performance of ports or the prospects for developing competitive advantages. Whereas, financial analyses are not suitable to study port performance.

Therefore, the purpose of this paper is to develop the evaluation model of seaports 'performance that would enable assessing the financial situation of the organisation and determining its position in the market in relation to its competitors. The article analyses the factors of business competitiveness and the methods for their evaluation as well as the theoretical aspects of applying financial analysis. After different methodologies and evaluation models proposed by different authors are analysed, the economic evaluation model of port performance developed by the authors of the present article is presented. By applying this model, the evaluation of the performance of the Baltic seaports is carried out.
\end{abstract}

Keywords: Competitiveness; Financial Analysis; Performance Evaluation; Port; Economic Model.

\section{Introduction}

Solving the problems of competition is very important not only in the theory of economics and management, but also in the economic activity - at the levels of both business and the state. It is becoming more and more relevant to withstand the increasing overall competitive pressure arising due to the liberalization of markets for goods and services as well as the ability to meet the strengthened business conditions.

A key role in the market is played by competition. It functions as the driving force to stimulate innovation, efficiency and freedom of choice, the latter of which forces companies to reduce prices and in other ways focus on their consumer needs. Meanwhile, company owners, executives and other investors need reliable and detailed information on the evaluation of financial performance.

Despite major differences in the economic development, in the Baltic Sea region there are excellent examples of competitive, knowledge-based economic development, therefore closer cooperation and application of best practices is one of the guarantees of success.

Seaports operate on a highly competitive global transport market. To retain its competitive position a port (terminal) must strengthen its competitive advantages in all fields of activity. Ports are to expand and modernize their infrastructure and superstructure, and develop links with the hinterland and the foreland (Palmowski \& Tarkowski, 2016).

Relevance of the topic and the scientific problem. Traditionally, the performance of ports has been evaluated in order to calculate and improve or optimise performance productivity in the area of cargo handling by comparing its actual and optimum throughput.

Tongzon (1995) has conducted an empirical research on the performance results of 23 international ports and on the impact of port infrastructure on port efficiency. Kim (1997; Kim \& Bae, 1998) have analysed the influence of container arrangement and the number of rehandles between cranes on the efficiency of the port. Wilson and Roach (2000) have analysed the possibilities of using artificial intelligence to optimize handling, the arrangement of cargoes and their storage in ports. To sum up, it can be stated that if the actual turnover of a port approximates (deviates from) optimal efficiency over certain period, it is concluded that its performance has improved (deteriorated) over time. Engineering optimum throughput was usually defined as the maximum throughput, i.e. how much cargoes a port can physically handle under certain conditions. However, there have been only a few attempts to accomplish a generalized evaluation of the efficiency of a port. Usually only one factor is measured - port's productivity. For example, Chen et al. (2016) propose a framework that takes the ships' container-handling events at terminals as the basis for port 
performance measurement. They offer to leverage the pervasive ship GPS traces and maritime open data to derive port performance indicators, including ship traffic, container throughput, berth utilization, and terminal productivity, instead of relying on the manually collected statistical information from different port authorities and shipping companies.

In 1994 Talley proposed a set of indicators to evaluate the performance of ports considering the economic optimum beyond engineering parameters. More recently, new PPIs have been proposed to cover the current needs of ports, including logistics services, for instance. As an indication, Owino, Wang and Pasukeviciute (2006) produced an updated list with 30 different performance indicators and Marlow and Paixao (2003), proposed a set of PPIs highlighting the importance of measuring port effectiveness and its relationship with leanness in the entire logistics transport chain. In the same context, Bichou and Gray (2004) based performance on logistics services, and argued that all performance indicators can be reduced to three broad categories: physical, productivity; and economic and financial indicators (Fusco, Sauri, Lekka, \& Karousos, 2016).

Previous studies on port performance generally consider the port performance indicators as independent attributes (Yeo, Ng, Lee, \& Yang, 2014). However, considering PPIs as independent and irrelevant to each other can be error prone to solve multiple criteria decision making problems in complex port activities and operations (Lee, Wu, Hu, \& Flynn, 2013).

Ha, Yang, Notteboom, Ng \& Heo (2017) presented a hybrid model that measures PPIs and the interdependency among PPIs in a quantitative manner by taking the perspectives from different port stakeholders. As port management becomes market-oriented and actor-centred (i.e., multi-stakeholder environment), port research and investigation need to focus on the firm level (i.e., actor-, terminal, firm-centred) rather than just on the port level (Woo, Pettit, Beresford, Kwak, \& Woo, 2012). A comprehensive analysis of port performance helps port managers to make better decisions on port operations (Ha et al., 2017).

In recent years, two more advanced holistic methods have been used to measure port efficiency: Data Envelopment Analysis (hereinafter referred to as DEA) and Stochastic Frontier Analysis (hereinafter referred to as SFA). There are numerous applications using Data Envelopment Analysis (DEA) models to estimate efficiency in ports, for example: Schoyen et al. (2018) used DEA to focus on sensitivities to the inclusion of country-specific measurements on logistics service delivery performance outcomes on port efficiency; Wang \& Han (2018) measured the efficiency of international ports analysing six inputs of twelve international container ports in Taiwan (application service process, service personnel ability, service personnel attitude, advisory services, harbour rates and stevedoring rates), and seven outputs (tug boat operation, rope untwisting operation, pilot operation, stevedoring efficiency, low damage rate for goods, awaiting unloading and working, and service flexibility); Pjevcevic, Dimitrijevic, Bisevac, \& Vukadinovic (2018) presented a decision-making process of selecting the most efficient technology for dry bulk cargo handling at an inland port
(DEA models were used to identify the most efficient variant).

It must be noted, that SFA method is more rarely used to evaluate port efficiency: H. Chen, Chou, \& Hsieh (2018) applied SFA method to study output and disaggregate input efficiencies of international container ports during 20042011 to identify avenues for strengthening port operations; Wiegmans \& Witte (2017) focused on determining and analyzing terminal characteristics that influence efficiency of inland waterway container terminals (IWTs).

To sum up, in port performance, not only physical ability to handle the flow of cargo, but also the potential competition for cargo is important. The methods presented in the scientific literature provide with an opportunity to evaluate only the technical efficiency of ports, completely excluding the aspect of financial performance of ports or the prospects for developing competitive advantages. Whereas, financial analyses are not suitable to study port performance.

For this reason, it is necessary to develop the evaluation model of port performance which would complement the DEA and SFA models and would allow evaluating the financial situation of ports as economic units and determining the factors of successful competitiveness.

The object of this research is the evaluation of the performance of the Baltic seaports.

The purpose is to develop the evaluation model of seaports' performance that would enable assessing the financial situation of the organisation and determining its position in the market in relation to its competitors. Test the model in order to see if the model needs any changes by evaluating the Baltic seaports' performance.

Methods of the research. In the course of the analysis on the factors of business competitiveness and their evaluation models, as well as the methods and peculiarities of economic-financial analysis of an organization, the systematic, comparative and logical analysis of the scientific Lithuanian and foreign literature and legal acts has been employed. The methods of statistical analysis of secondary data and comparative analysis have been applied to evaluate the performance of seaports. The theoretical data processing method has been used to summarize and present conclusions and recommendations.

\section{Evaluation Methods}

After a deeper analysis of definitions of the concept of competition it may be stated that competition is a process of competing for economic benefits, although the main goal may not always be generating more profits. According to the research, in individual cases, companies, wishing to win a larger part of the market, sacrifice part of their profits - sell their products or services at lower prices.

The leading research programme on performance development and enterprise transformation explores why some companies win new businesses, build relationships with clients, develop and use knowledge and manage change, while others stagnate. Teams of researchers compare the methods and the practices applied in the most and least successful companies in order to identify the essential factors of successful competitiveness. The majority of the distinguished success factors belong to the group of behavioural factors. Among them are the 
following: to remain relevant and important: to create additional flows of income; to strengthen capacities and to renew intellectual capital; to create additional opportunities and to expand the search: to start up new businesses and to create new markets; to show the will to win: to anticipate future conditions and to plan their actions respectively by establishing priorities and long-term goals; to inspire and motivate: to make sure people understand what they have to do and have obviously done; to understand their clients and to ensure that they are not damaged by changes; to be proactive: do not wait for the changes to be inevitable but to show initiative (Coulson-Thomas, 2005).

The methods for evaluating competitiveness can be divided into five groups: 1) methods for evaluating the indicators of competitiveness (price competitiveness evaluation methods; non-price-based competitiveness evaluation methods); 2) methods for evaluating competitiveness of economic sectors (macroeconomic analysis and the analysis of economic performance of branch enterprises; comparative analysis; the "Diamond Model" introduced by Porter (1990) and Global Capital Access Index introduced by Milken Institute (California, USA); 3) methods for evaluating competitiveness at the level of a region / country (The European Competitiveness Index; The Massachusetts Innovation Economy Index; UK Competitiveness Index); 4) methods for evaluating competitiveness at the international level (Global Competitiveness Indicators of states and regions by the World Economic Forum; World Competitiveness Index by the International Management Development Institute established in Switzerland); 5) methods for evaluating competitiveness of economic policy (Index of Economic Freedom by the Heritage Foundation established in Massachusetts (USA).

Over four decades, the university professor Michael E. Porter (hereinafter referred to as MEP) has developed the flow of conceptual models, usually starting with the letter "C": competition; competitive strategy; competitive advantage; competitiveness; clusters and creation of value (Porter, 2003).

The "Diamond Model" introduced a system of four interrelated microeconomic users: factor conditions, demand conditions, strategy and competition, supply and related industries. The "National Diamond Model" acts as a system. Zhou (2015) stated that diamond system is a system for biaxial strengthening and interaction, which means that the effect of each factor influences the states of the others. It is possible to form the self-reinforcing business advantage by combing all factors organically and being applied comprehensively.

Cho, the author of "The Nine-Factor Model" (presented for the first time in 1994), sought to show who and how creates competitive advantage of countries. Unlike the "National Diamond Model", where natural and human resources are ascribed to factor conditions, "The NineFactor Model" identifies natural resources as inherited resources and delivers human resources more in detail in order to emphasise the importance of knowledge-based long-term competitive advantage of a country. Cho \& Moon (2012) argued that human resources create, manage and control physical factors; therefore the economy of a country is shifted from one level of competitiveness to another.
In conclusion, it can be stated that the process of evaluating competitiveness requires time, finances, and often human resources. Not only the accuracy of the evaluation results, their value, but also the complexity of the evaluation process, the cost and expediency of applying the methods depend on the comprehensiveness of methods and on the degree of detail. The main methodological problems arising in the process of evaluating competitiveness are the lack of a unified, clear concept of competitiveness and the constraints imposed by the evaluation methodologies. At the practical level, there is a lack of time and financial resources as well as restrictions imposed by the availability of information.

\section{Economic-financial evaluation of an organisation}

Economic literature does not offer unified approach towards financial analysis. The methods of financial analysis of a company are processing, generalisation and systematisation of the sources of analysis. The research methods of other sciences are also applied in financial analysis; therefore different authors present different classifications of these methods. The methods for investigating financial analysis presented in the works by some authors often coincide with the types of financial analysis by other authors; they are: horizontal, relative, vertical, grouping and comparing. Such a variety of methods of analysis enables to analyse, predict and compare the available and expected results in various aspects. The result is an effective and comprehensive early warning system that measures and takes into account the performance of the enterprise. This instrument can detect weaknesses and problems that are to be resolved and also highlights the strengths on which the company can rely (Medvecka, Binasova, \& Kubinec, 2017).

There are the three most commonly distinguished methods for evaluating financial performance: horizontal analysis, vertical analysis and relative analysis. Horizontal analysis is almost identical to the analysis of lines of dynamics. It is often used to analyse the balance sheet and profit (loss) report data of a company. The main disadvantage of horizontal analysis - the comparison with previous periods does not give any basis to decide the absolute level of results achieved and does not investigate into the reasons of change. Vertical analysis is identical to calculation of comparative weights, when each indicator of financial report is compared to the general base indicator of that report and the obtained value is expressed as a percentage. It enables to observe the interconnection and influence of individual elements of the system and to draw conclusions about the reasons for the change in one or other phenomena. Relative analysis is also called the analysis of financial ratios. Financial ratios are grouped into groups of systems that are commonly referred to as profitability, efficiency, solvency, stability, markets. The main advantages of relative analysis are the following: the fastest way to get the most information; relative indicators are much more favourable compared to absolute indicators. The main drawbacks of relative analysis are: it analyses only relative indicators rather than absolute indicators that would express individual articles of company assets or property owners and liabilities.

To sum up, it can be argued that the evaluation of financial results helps to better understand the phenomena 
Aranka Ignasiak-Szulc, Vytautas Juscius, Bogatova Jelena. Economic Evaluation Model of Seaports’ Performance...

and processes occurring in a company, to properly and objectively assess the economic information of a company which in turn help to make efficient long-term management decisions.

\section{Methodology of the Research}

The evaluation model of the Baltic seaports is comprised of three stages of evaluation:

Stage I. Evaluation of the competitiveness of an organisation. Based on literature review, it can be stated that there is no single common theoretical method for evaluating competitiveness of a port. Different authors emphasize different factors determining competitiveness of a port. The importance of strengthening the competitiveness of ports is often mentioned, but methodological models of competitiveness that would comprehensively cover all the main determinants of competitiveness of a port are lacking. The analysis of the scientific literature has revealed that only the complex and systematic management of port performance could determine successful competitiveness of a port in the international market.
According to the accomplished analysis on the evaluation models of business competitiveness and various researchers and availability of information, the evaluation model of competitiveness of the Baltic ports has been developed (see Figure 1):

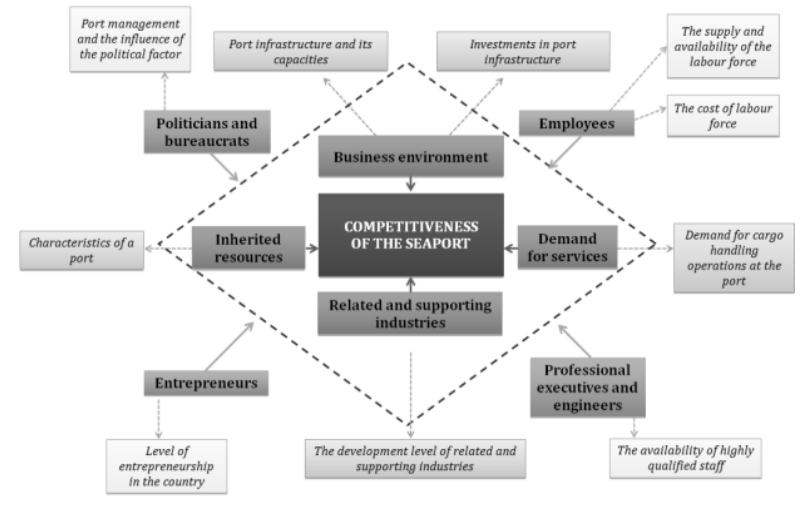

Figure 1. The Stage for Evaluating Competitiveness of the Baltic Seaports According to the Evaluation Model of Performance

Table 1

Indicators for Evaluating Competitiveness

\begin{tabular}{|c|c|c|}
\hline Group of factors & Factors & Indicators \\
\hline \multirow{4}{*}{ Business environment } & \multirow{3}{*}{ Investments in port infrastructure } & Investment volume (mln. Euro) \\
\hline & & $\begin{array}{l}\text { The correlation between the volume of investments and the volume of cargo } \\
\text { handling }\end{array}$ \\
\hline & & $\begin{array}{l}\text { The attraction of the European Union funds for investments (percent of the total } \\
\text { investment volume) }\end{array}$ \\
\hline & Port infrastructure and its capacities & Storage areas (sq. m) \\
\hline \multirow{3}{*}{ Inherited resources } & \multirow{3}{*}{ Characteristics of a port } & Shipping conditions in the winter season \\
\hline & & Characteristics of the water territory \\
\hline & & Maximum ship sizes that can be accepted by the port \\
\hline \multirow{3}{*}{ Domestic demand } & \multirow{3}{*}{$\begin{array}{l}\text { Demand for cargo handling operations } \\
\text { at the port }\end{array}$} & Cargo handling volumes (mln. tons) \\
\hline & & Structure of cargo handling operations (percent) \\
\hline & & Volumes of cargo handling operations by type of cargo (mln. tons) \\
\hline \multirow{2}{*}{$\begin{array}{l}\text { Professional executives } \\
\text { and engineers }\end{array}$} & \multirow{2}{*}{ The availability of highly qualified staff } & Number of students in higher education institutions (per 1000 inhabitants) \\
\hline & & Number of graduates of higher education institutions (per 1000 inhabitants) \\
\hline \multirow{5}{*}{ Employees } & \multirow{3}{*}{$\begin{array}{l}\text { The supply and availability of the } \\
\text { labour force }\end{array}$} & Economically active population (per 1000 inhabitants) \\
\hline & & Employment, percent from the working-age inhabitants \\
\hline & & Unemployed inhabitants of working age (per 1000 inhabitants) \\
\hline & \multirow{2}{*}{ The cost of labour force } & Labour cost level (Euro) \\
\hline & & Minimum monthly salary (Euro) \\
\hline Entrepreneurs & Level of entrepreneurship in the region & Entrepreneurship indicators in 7 dimensions. \\
\hline $\begin{array}{l}\text { Politicians and } \\
\text { bureaucrats }\end{array}$ & $\begin{array}{l}\text { Port management and the influence of } \\
\text { the political factor }\end{array}$ & Qualitative evaluation \\
\hline
\end{tabular}

Stage II. Economic-financial evaluation of the performance of an organisation. The economic-financial evaluation of the performance of the Baltic seaports includes:

1. Horizontal and vertical analysis of the performance results of major ports;

2. The analysis of relative indicators:

The analysis of the efficiency of performance indicators. The evaluation on the efficiency of performance includes the analysis of: inventory turnover, fixed asset turnover, current asset turnover, total asset turnover, receivables turnover, accounts payable turnover, operating and cash cycles, operating costs and mobility index.

The analysis of solvency (liquidity) ratios. The evaluation of solvency (liquidity) of an organization includes the analysis of: the general current solvency ratio, the quick current solvency ratio, the current solvency ratio of the capital employed, the absolute current solvency ratio, the sales commission ratio, solvency ratios, the general debt ratio, "the golden rule of balance sheet", financial leverage, debt-equity ratio, shareholder equity and debt ratio, debt indemnity in cash ratio, debt-the capital employed ratio, fixed debt indemnity in capital employed ratio, equity multiplier and fixed debt ratio.

The analysis of profitability indicators. The evaluation of profitability of an organisation includes the analysis of: general profit, operating profit, net profit margin, return on owners equity (ROOE), return on capital employed (ROCE) and return on assets (ROA). 
Stage III. Data normalization and the evaluation of total results. Since in the stages I and II of the evaluation model of the performance of the Baltic seaports, the features of the analysed objects are characterized by different indicators, there is a need to formulate a correct evaluation procedure that would allow different indicators be evaluated among themselves (Chakravarty, 2003). Therefore, in order to combine the variables into a common index, the value of each indicator is normalized (Caselli, 2008; Ray, 2008). Normalization is carried out by using the method of distance from the average of a group according to the formula, where $100 \%$ is assigned to the average value of a group:

$$
I_{q c}^{t}=\frac{x_{q c}^{t}}{x_{q c=\bar{c}}^{t_{0}}}
$$

Or, if the lower value of an indicator is evaluated positively:

$$
I_{q c}^{t}=2-\frac{x_{q c}^{t}}{x_{q c=\bar{c}}^{t_{0}}}
$$

To sum up, it can be stated that the proposed economic evaluation model of the performance of the Baltic seaports assesses the financial-economic condition of ports and, based on the calculated evaluation index, enables to determine the position of a particular port in relation to its competitors and to establish correlations between the various aspects of evaluation.

\section{The Results of the Research}

For the analysis three major Baltic ports have been selected: Klaipeda State Seaport (hereinafter the Port or the KSSP), Freeport of Riga and the Port of Tallinn.

Stage I. Evaluation of the competitiveness of an organisation.

\section{Business environment}

The evaluation of port infrastructure. The port of Riga has the largest outdoor storage areas among the Baltic ports, most of which are used for storing coal and containers. Large storage areas are especially needed for storing bulk cargoes because they must be sorted according to their quality. In addition, such cargoes often come to ports from different customers, who, in turn, require the goods to be classified according to their type, quality and owner.

The evaluation of investments in port infrastructure. Since the Freeport of Riga does not provide data on the volume of implemented investments for the period of 2014-2016, indicators related to investment analysis have not been included in the evaluation of competitiveness of the Baltic seaports.

\section{Inherited resources}

The evaluation of shipping conditions in the winter season. The port of Klaipeda is completely ice-free, whereas shipping conditions in the winter season are more difficult in the ports of Tallinn and Riga; but both these ports have the necessary equipment (icebreakers) which guarantees year-round shipping. For this reason, it can be argued that the geographical position does not provide competitive advantages to any of the investigated ports and will not be further analysed.

The evaluation of the characteristics of the water territory. The port of Tallinn, which is a seaport, is capable of providing depths up to 18 meters. The ports of Riga and Klaipeda are located in the gulfs and therefore cannot guarantee the maximum specified depth in all locations of the shipping channel. The port of Klaipeda provides a depth up to 15 meters, while the port of Riga - up to 16 meters.

Domestic demand

Domestic demand is understood as the demand for handling operations at the port. It is evaluated by taking into account 3 indicators: cargo handling volumes (mln. tons); structure of cargo handling operations (percent); volumes of cargo handling operations by type of cargo ( $\mathrm{mln}$. tons). The more cargo is served in the port, the higher is its level of competitiveness. A significant impact is also felt by the differentiation of goods or, in some cases, specialization. Therefore, leader positions in handling certain type of cargo and a sufficient degree of differentiation in the structure of the volume of cargo handling are especially favourably evaluated. Summarizing the analysis, it can be argued that Riga and Tallinn compete with Russian ports in handling the main cargo groups, while Klaipeda has secured leading positions in handling other types of cargo whereby its stability is ensured.

\section{Professional executives and engineers}

The group of factors of professional executives and engineers is evaluated by analysing the availability of highly qualified staff in the region. Summarizing the analysis, it can be argued that Lithuania has the highest availability of higher education, while Estonia has the lowest availability. The port of Klaipeda has a high potential of qualified labour force and the possibility to attract it at the lowest cost, because in the region there are many qualified people, the level of wages is significantly lower than the average of the EU or competing countries, though it is significantly higher than the average of the country, which ensures loyalty of qualified employees.

Employees

After the evaluation of supply and availability of labour force in the Baltic States, it can be concluded that the leading position in this category is occupied by Estonia. Meanwhile, Lithuanian and Latvian indicators are very similar. Assessing labour costs of the Baltic States, it is observed that the cheapest labour force is in Lithuania. Minimum monthly salary approved by the state in 2014-2016 was also the smallest in Lithuania. To conclude, the supply and availability of the labour force is highest in Estonia, although the cost of labour force is also quite high.

\section{Entrepreneurs}

The results of the Global Entrepreneurship Monitor (GEM) survey revealed that, in assessing the 7 entrepreneurial dimensions, Lithuanian results more or less correspond the indicators of the EU. Meanwhile, the indicators of Latvia and Estonia are very similar and considerably exceed the average of Lithuania and the EU in the dimensions of early entrepreneurship and corporate entrepreneurship. However, to sum up, despite some differences, the entrepreneurship is very similar in all three countries, therefore this factor does not provide competitive advantage to the analysed ports, and therefore, it will not be further included in the evaluation of competitiveness.

\section{Politicians and bureaucrats}

Based on the accomplished analysis of port management, it can be concluded that the state plays a significant role in the management of all three ports. Although, according to experts, the influence of political 
factor on port management is very high in Riga, this factor does not provide the ports with competitive advantage, therefore it will not be further evaluated.

Stage II. Economic-financial evaluation of the performance of an organisation

The horizontal and vertical analysis of the performance results of Klaipeda State Seaport has revealed that fixed assets comprise the largest part in the asset structure of the port of Klaipeda - even $92 \%$, and during the analysed period they have increased by $3 \%$. It implies that the port of Klaipeda makes investments in the development of its operations, i.e. acquisition or renewal of fixed assets. The analysis of the trends of changes in the current assets, has indicated that the accounts receivable during the considered period have decreased by $30 \%$. It should be also noted that in the structure of current assets, accounts receivable make up only an insignificant part (about 16\%), which indicates that the port of Klaipeda has no problems with accounts receivable. The analysis of the structure of property and liabilities has indicated that the port of Klaipeda finances most of its activities from its own funds, i.e. equity capital in the structure of property and liabilities accounts for more than $90 \%$, while long-term debts comprise less than $4 \%$. It should be noted that part of long-term debts have decreased continuously over the considered period and in 2016 it comprised only $1.5 \%$, while equity capital has increased by $8.5 \%$, which indicates of the investment policy of the port of Klaipeda. As regards the trends of income of Klaipeda State Seaport, it should be noted that they have grown by 13 $\%$ during the analysed period, operating costs on an average comprised $49 \%$, and net profit $-48 \%$ of income.

The horizontal and vertical analysis of the performance results of the port of Riga enables to state that fixed assets constitute the largest part in the asset structure of the port of Riga - even $97 \%$, and they have increased by $12 \%$ during the analysed period. This implies of investments by the Port of Riga in the development of its operations, i.e. acquisition or renewal of fixed assets. It should be noted that the largest part of the structure of current assets is comprised of cash and cash equivalents. The analysis of the structure of property and liabilities has revealed that the port of Riga finances most of its activities from long-term liabilities, which in the structure of property and liabilities, make up even $81 \%$. It should be noted that over the considered period part of long-term debts have increased by $56 \%$ from 85 million Euro to 134 million Euro, while equity capital has remained unchanged and short-term liabilities have decreased almost two times; it implies the renewal of depreciable assets and the redistribution of short-term lending liabilities. As regards the trends of change in income of the port of Riga, it should be noted that during the analysed period it has decreased by $11 \%$.

The horizontal and vertical analysis of the performance results of AS Tallinna Sadam has revealed that fixed assets in the asset structure of the port of Tallinn also comprise the largest part - even $90 \%$, and they have increased by $13 \%$ during the analysed period. The analysis of the trends of changes in the current assets has revealed that during the analysed period they have increased 1.5 times, which is explained by the increase in cash balance and inventories. After analysing the structure of property and liabilities, it has turned out that the port of Tallinn finances most of its activities from its own funds, i.e. equity capital comprises about $60 \%$ in the structure of property and liabilities, while long-term debts account for only about $30 \%$. It should be noted that the short-term lending liabilities of the port of Tallinn over the considered period have increased more than two times and in the total structure of capital and liabilities in 2016 it made up even $22 \%$. Regarding the trends of change in the income of the port of Tallinn, it should be noted that during the analysed period it has decreased by 13 $\%$, which can be explained by the decreasing volumes of handling. Operating costs have increased marginally (5\%). During the analysed period, operating profit has been on an average $37 \%$, while net profit has been $36 \%$. Therefore, it can be argued that the Authority of the Port of Tallinn successfully reduces the effects of the current market situation by increasing income from other activities.

To sum up, the asset structure of all three ports is dominated by fixed assets, while in the structure of property and liabilities the equity capital considerably exceeds longterm liabilities. All the analysed ports are operating profitably and the general net profit trend is noticeable. The largest margin of profit is in the port of Klaipeda and on average accounts for $48 \%$.

The analysis of relative indicators:

1. The evaluation of the efficiency of performance. After analysing the efficiency indicators of the Baltic seaports, it can be stated that turnover indicators are evaluated to be positive. As regards the level of operating costs, it should be noted that it is the lowest in the port of Klaipeda (on average $48 \%$ of income), and the highest in the Freeport of Riga (on average $80 \%$ of income). However, the operating costs of all three ports concerned do not exceed the recommended levels. During the analysed period, the Mobility Index has decreased only in the port of Riga, which is associated with the decrease in current assets: reduction of the level of inventories, realization or write-off of other current assets and reduction of cash balance.

2. The evaluation of solvency (liquidity). After the analysis of solvency (liquidity) of the Baltic seaports, it can be concluded that the coverage ratio in the ports of Riga and Tallinn during the period of 2014-2016 has been lower (average values 1.1 and 0.7 , respectively) than recommended (recommended ratio is 2). For this reason, it can be assumed that the ports of Riga and Tallinn could have encountered problems in meeting their short-term liabilities. However, it can be also stated that the values of such an indicator are advantageous for port owners seeking to make the best use of the available current assets. It must be noted that almost all of the current assets held in ports are classified as mobile, therefore the indicator of solvency speed in the ports of Klaipeda and Riga has exceeded the recommended value (recommended ratio 1). Liquidity in cash is also evaluated to be positive, because coverage in cash ratio in the analysed ports exceeds the recommended $0.2-0.25$ ratio. On the other hand, it can be concluded that the available money is used inefficiently, since in all ports this indicator has exceeded the recommended value more than two times.

The general debt ratio in all ports is very small, which indicates that only a small part of assets is financed by borrowed funds. Debt ratio is especially low in the port of Klaipeda (0.035), therefore, in order to receive higher 
income it is recommended to finance a larger part of assets with borrowed funds. The analysis of the "Golden rule of balance sheet" ratio revealed that capital employed is almost sufficient for financing fixed assets in all ports.

In conclusion, the ports of Klaipeda, Riga and Tallinn are not only solvent and liquid, but it is also recommended to increase the size of the borrowed capital, i.e. to fund more assets with borrowed funds in order to increase profitability.

3. The evaluation of profitability. After the analysis of profitability of the Baltic ports it has turned out that all the analysed ports are operating profitably. The most profitable of them is the port of Klaipeda - its profitability during the analysed period was on average $51 \%$, while its net profit was $48 \%$. The Freeport of Riga was the least profitable - its operating profitability during the analysed period was $20 \%$ and its net profit $18 \%$.

Analysing the profitability of equity and capital employed, it should be noted that the best results in these categories are shown by the Port of Tallinn (the average value of equity returns during the years 2014-2016 was $10.5 \%$, and the average value of profitability of capital employed was $9.37 \%$ ). In the port of Klaipeda, the average value of equity returns amounted to $5.58 \%$ during the period and the average value of the profitability of capital employed was $6.04 \%$; while in the port of Riga - these values were $3.57 \%$ and $2.68 \%$, respectively. The indicator of return on assets during the analysed period was also the highest in the port of Tallinn (6.22\%), and the lowest return on assets was recorded in the port of Riga (2.37\%).

To sum up, the analysis of the profitability of the Baltic seaports has revealed the position of the ports of Klaipeda and Tallinn as leaders in all categories.

Stage III. Data normalization and the evaluation of total results.

Normalized data of the stage I evaluation of competitiveness of the Baltic seaports is presented in Table 2. All groups of factors of competitiveness have the same weight in port evaluation.

Table 2

Total results of the stage I evaluation of competitiveness of the Baltic seaports

\begin{tabular}{|l|c|c|c|}
\hline & $\begin{array}{c}\text { Port of } \\
\text { Tallinn }\end{array}$ & $\begin{array}{c}\text { Klaipeda } \\
\text { State } \\
\text { Seaport }\end{array}$ & $\begin{array}{c}\text { Freeport } \\
\text { of Riga }\end{array}$ \\
\hline Business environment & $\mathbf{3 . 5 9 6}$ & 1.973 & 3.432 \\
\hline Inherited resources & 3.483 & $\mathbf{4 . 7 9 0}$ & 3.727 \\
\hline Domestic demand & 0.696 & 1.138 & $\mathbf{1 . 1 6 6}$ \\
\hline $\begin{array}{l}\text { Professional } \\
\text { executives and } \\
\text { engineers }\end{array}$ & 0.902 & $\mathbf{1 . 1 4 3}$ & 0.955 \\
\hline Employees & 4.459 & 5.267 & $\mathbf{5 . 2 7 4}$ \\
\hline $\begin{array}{l}\text { Total score of } \\
\text { competitiveness }\end{array}$ & 13.136 & 14.311 & $\mathbf{1 4 . 5 5 3}$ \\
\hline $\begin{array}{l}\text { The index value of } \\
\text { distance from the } \\
\text { average of a group }\end{array}$ & 0.938 & 1.022 & $\mathbf{1 . 0 4 0}$ \\
\hline
\end{tabular}

After the analysis of the competitiveness of the Baltic seaports and the normalization of the obtained results by using the method of distance from the average of a group, taking into account the change in indicators during the period of 2014-2016, it can be concluded that the most competitive scores have been collected by the Freeport of Riga (14.553), Klaipeda port (14.311) has remained in the second position and the port of Tallinn (13.136) - in the third position. It must be noted that the Freeport of Riga acquired competitive advantage in the groups of "Domestic demand" (however, the demand has decreased by $10 \%$ during the analyzed period, and in 2016 Klaipeda State Seaport already exceeded the total amount of cargo handled in Riga) and "Employees". Therefore, being a leader the Freeport of Riga in respect to other Baltic ports cannot be evaluated unambiguously.

The port of Klaipeda acquires competitive advantages in 2 categories: "Inherited resources"; "Professional executives and engineers". Meanwhile, the port of Tallinn in the group of factors of "Business environment".

Since the analysis of solvency (liquidity) has not revealed significant differences among the Baltic ports, in order to generalize the results of the economic-financial evaluation it is purposeful to carry out the normalization of the relative indicators of profitability and efficiency (see Table 3). Normalization is carried out by using the method of distance from the average of a group according to formulas (1) and (2).

Table 3

Normalization of the evaluation results of profitability and efficiency of the Baltic seaports

\begin{tabular}{|l|c|c|c|}
\hline \multicolumn{1}{|c|}{ Indicators } & $\begin{array}{c}\text { Klaipeda } \\
\text { State } \\
\text { Seaport }\end{array}$ & $\begin{array}{c}\text { Freeport } \\
\text { of Riga }\end{array}$ & $\begin{array}{c}\text { Port of } \\
\text { Tallinn }\end{array}$ \\
\hline \multicolumn{3}{|c|}{ The evaluation results of profitability } \\
\hline Operating profit & 1.370 & 0.542 & 1.089 \\
\hline Net profit margin & 1.412 & 0.522 & 1.066 \\
\hline $\begin{array}{l}\text { Return on owners equity } \\
\text { ROOE) }\end{array}$ & 0.852 & 0.545 & 1.603 \\
\hline $\begin{array}{l}\text { Return on capital employed } \\
\text { (ROCE) }\end{array}$ & 1.002 & 0.445 & 1.553 \\
\hline $\begin{array}{l}\text { Return on assets (ROA), } \\
\text { percent }\end{array}$ & 1.079 & 0.529 & 1.391 \\
\hline $\begin{array}{l}\text { Total score of the evaluation } \\
\text { of profitability }\end{array}$ & $\mathbf{5 . 7 1 5}$ & $\mathbf{2 . 5 8 3}$ & $\mathbf{6 . 7 0 2}$ \\
\hline \multicolumn{1}{|c|}{ The evaluation results of efficiency } \\
\hline Inventory turnover & 0.240 & 0.619 & 2.141 \\
\hline Current asset turnover & 0.724 & 1.299 & 0.977 \\
\hline Fixed asset turnover & 0.750 & 0.943 & 1.307 \\
\hline Total asset turnover & 0.750 & 0.960 & 1.289 \\
\hline Receivables turnover & 1.022 & 1.339 & 0.639 \\
\hline Accounts payable turnover & 0.485 & 0.652 & 0.311 \\
\hline Cash cycle & 0.874 & 1.065 & 1.060 \\
\hline Operating costs & 1.220 & 0.728 & 1.052 \\
\hline $\begin{array}{l}\text { Total score of the evaluation } \\
\text { of profitability }\end{array}$ & $\mathbf{6 . 0 6 5}$ & $\mathbf{7 . 6 0 6}$ & $\mathbf{8 . 7 7 7}$ \\
\hline $\begin{array}{l}\text { Total score of the evaluation } \\
\text { of profitability of the stage II }\end{array}$ & $\mathbf{1 1 . 7 8 1}$ & $\mathbf{1 0 . 1 8 9}$ & $\mathbf{1 5 . 4 7 8}$ \\
\hline $\begin{array}{l}\text { The index value of distance } \\
\text { from the average of a group }\end{array}$ & $\mathbf{0 . 9 4 4}$ & $\mathbf{0 . 8 1 6}$ & $\mathbf{1 . 2 4 0}$ \\
\hline
\end{tabular}

After the normalization of the results of profitability and efficiency analysis, it has turned out that the most profitable and effective in performance is the port of Tallinn, which collected 6.702 scores of profitability and 8.777 scores of efficiency.

\section{Conclusions}

Only the general models for evaluating competitiveness are offered and analysed in the scientific literature; those models differ in scope, goals and objects of evaluation. In evaluating the competitiveness of ports, the 
authors do not use particular models; they only distinguish and assess different factors determining competitiveness. Michael E. Porter has developed the flow of conceptual models for evaluating competitiveness, the most popular of which is the "National Diamond Model". However, his proposed model for evaluating competitiveness has several drawbacks, therefore to eliminate these disadvantages other researchers have proposed their models for evaluating competitiveness: the "Double Diamond Model", "The NineFactor Model", etc.

The analysis of financial results determines the financial aspects of the performance of a company, the advantages and drawbacks of its activities, accurately assesses the current situation in a competitive environment and future prospects. There are the three most commonly distinguished methods for evaluating financial performance: horizontal analysis, vertical analysis and relative analysis. Horizontal analysis is almost identical to the analysis of lines of dynamics. It is often used to analyse the balance sheet and profit (loss) report data of a company. Vertical analysis allows monitoring the interconnection and influence of individual elements of the system and drawing conclusions about the reasons for the change in one or another phenomenon, since any change in the status of one element affects others. Relative analysis in theory and practice is also called the analysis of financial ratios. Financial ratios are grouped into systems, which are commonly referred to as profitability, efficiency, solvency, stability, markets.
The Economic Evaluation Model of Seaports consists of three stages: assessment of the organization's competitiveness, economic-financial evaluation of the organization's activities and normalization of data and evaluation of total results. The proposed economic model for assessing the performance of the seaports assesses the financial and economic status of the ports, and, based on the calculated evaluation index, allows determining the situation of a particular port in relation to its competitors and identifying correlations among various aspects of evaluation.

Summarizing the accomplished economic evaluation of the performance of the Baltic seaports, it can be stated that the port of Klaipeda acquires competitive advantages in 2 groups of factors: "Inherited Resources" and "Professional executives and engineers"; the port of Riga acquires competitive advantages in the groups of factors of "Domestic demand" and "Employees", while the port of Tallinn in the group of factors of "Business environment".

The port of Tallinn has secured the leading position among the Baltic ports (30.032 total scores), however, taking into account the rapidly developing port of Ust-Luga, which focuses on reloading of oil cargo, Tallinn is at risk of losing cargo flows. For this reason, it is necessary for it to increase its flexibility by differentiating the flows of goods served. The port of Klaipeda (24.917 scores) needs to increase its efficiency and further improve profitability of the company, thus strengthening its competitive position. The authorities of the port of Riga (24,499 scores) need to focus on increasing flexibility and profitability.

\section{References}

Bichou, K., \& Gray, R. (2004). A logistics and supply chain management approach to port performance measurement. Maritime Policy \& Management, 31(1), 47-67. https://doi.org/10.1080/0308883032000174454

Chen, H., Chou, H., \& Hsieh, C. (2018). Operational and disaggregate input efficiencies of international container ports: An application of stochastic frontier analysis. International Journal of Shipping and Transport Logistics, 10(2), 113-159. https://doi.org/10.1504/IJSTL.2018.10010279

Chen, L., Zhang, D., Ma, X., Wang, L., Li, S., Wu, Z., \& Pan, G. (2016). Container port performance measurement and comparison leveraging ship GPS traces and maritime open data. IEEE Transactions on Intelligent Transportation Systems, 17(5), 1227-1242. https://doi.org/10.1109/TITS.2015.2498409

Cho, D., \& Moon, H. (2012). Extended model (2): The nine-factor model. From Adam Smith to Michael Porter (pp. 143-165) World Scientific. https://doi.org/10.1142/9789814401661_0006

Coulson-Thomas, C. (2005). Leading a competitive company: Critical behaviors for competing and winning. Strategic Direction, 21(8), 3-5. https://doi.org/10.1108/02580540510606602

Fusco, P. M., Saurí, S., Lekka, A. M., \& Karousos, I. (2016). Assessing customs performance in the Mediterranean ports. KPI selection and best practices identification as part of the MEDNET project. Transportation Research Procedia, 18, 374-383. https://doi.org/10.1016/j.trpro.2016.12.049

Ha, M., Yang, Z., Notteboom, T., Ng, A., \& Heo, M. (2017). Revisiting port performance measurement: A hybrid multistakeholder framework for the modelling of port performance indicators. Transportation Research Part E: Logistics and Transportation Review, 103, 1-16. https://doi.org/10.1016/j.tre.2017.04.008

Kim, K. H. (1997). Evaluation of the number of rehandles in container yards. Computers \& Industrial Engineering, 32, 701-711. https://doi.org/10.1016/S0360-8352(97)00024-7

Kim, K. H., \& Bae, J. W. (1998). Re-marshaling export containers in port container terminals. Computers \& Industrial Engineering, 35, 655-658. https://doi.org/10.1016/S0360-8352(98)00182-X

Lee, P. T. W., Wu, J. Z., Hu, K. C., \& Flynn, M. (2013). Applying analytic network process (ANP) to rank critical success factors of waterfront redevelopment. International Journal of Shipping and Transport Logistics (IJSTL), 5(4), 390-411. https://doi.org/10.1504/IJSTL.2013.055276

Marlow, P. B., \& Paixao, A. C. (2003). Measuring lean ports performance. International Journal of Transport Management, 1(4), 189-202. https://doi.org/10.1016/j.ijtm.2003.12.002 
Medvecka, I., Binasova, V., \& Kubinec, L. (2017). Planning and performance evaluation of the manufacturing organizations. Procedia Engineering, 192, 46-51. https://doi.org/10.1016/j.proeng.2017.06.008

Owino, E. L., Wang, T., \& Pasukeviciute, I. (2006). Performance measurement in European container terminal industry: An empirical investigation. Paper presented at the International Association of Maritime Economists (IAME), Melbourne, Australia.

Palmowski, T., \& Tarkowski, M. (2016). Development of sea port in Gdynia. Baltic Region, (3), 61-74. https://doi.org/10.5 922/2079-8555-2016-3-4

Pjevcevic, D., Dimitrijevic, B., Bisevac, I. V., \& Vukadinovic, K. (2018). Design process of dry bulk cargo handling at an inland port: Case study of port Danube Pancevo. International Journal of Industrial Engineering - Theory Applications and Practice, 25(2), 267-282.

Porter, M. E. (2003). The economic performance of regions. Regional Studies, 37, 549-578. https://doi.org/10.1080/003434 0032000108688

Schøyen, H., Bjorbæk, C. T., Steger-Jensen, K., Bouhmala, N., Burki, U., Jensen, T. E., \& Berg, Ø. (2018). Measuring the contribution of logistics service delivery performance outcomes and deep-sea container liner connectivity on port efficiency. Research in Transportation Business \& Management, https://doi.org/10.1016/j.rtbm.2018.03.002

Tongzon, J. (1995). Determinants of port performance and efficiency. Transportation Research Part A: Policy and Practice, 29(3), 245-252. https://doi.org/10.1016/0965-8564(94)00032-6

Wang, Y., \& Han, T. (2018). Efficiency measurement for international container ports of Taiwan and surrounding areas by fuzzy data envelopment analysis. Journal of Marine Science and Technology-Taiwan, 26(2), 185-193. https://doi.org/10.6119/JMST.2018.04(2).0006

Wiegmans, B., \& Witte, P. (2017). Efficiency of inland waterway container terminals: Stochastic frontier and data envelopment analysis to analyze the capacity design and throughput efficiency. Transportation Research Part A: Policy and Practice, 106, 12-21. https://doi.org/10.1016/j.tra.2017.09.007

Wilson, I., \& Roach, P. (2000). Container stowage planning: A methodology for generating computerised solutions. Journal of the Operational Research Society, 51, 1248-1255. https://doi.org/10.1057/palgrave.jors.2601022

Woo, S., Pettit, S., Beresford, A., Kwak, D., \& Woo, S. (2012). Seaport research: A decadal analysis of trends and themes since the 1980s. Transport Reviews, 32(3), 351-377. https://doi.org/10.1080/01441647.2012.660996

Yeo, G., Ng, A. K. Y., Lee, P. T., \& Yang, Z. (2014). Modelling port choice in an uncertain environment. Maritime Policy Manage, 41(3), 251-267. https://doi.org/10.1080/03088839.2013.839515

Zhou, X. (2015). The construction of evaluation index system of aviation logistics industry. A case study of Zhengzhou airport-based zone. Paper presented at the International Conference on Logistics Engineering, Management and Computer Science (LEMCS 2015), Shenyang, China, 117, 367-370. https://doi.org/10.2991/lemcs-15.2015.71

The article has been reviewed. Received in July, 2018; accepted in December, 2018. 